Egyptian Journal of Aquatic Biology \& Fisheries

Zoology Department, Faculty of Science,

Ain Shams University, Cairo, Egypt.

ISSN $1110-6131$

Vol. 23(1): 341 -357 (2019)

www.ejabf.journals.ekb.eg

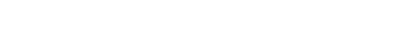

\title{
Water Quality Index and Microbial Assessment of Lake Qarun, El-Batts and El-Wadi Drains, Fayoum Province, Egypt
}

\author{
Afify D. G. Al-Afify; Usama M. Tahoun and Mohammed H. Abdo \\ National Institute of Oceanography and Fisheries (NIOF), Cairo, Egypt
}

\section{ARTICLE INFO}

Article History:

Received:Jan.5, 2019

Accepted: Feb. 26, 2019

Online: March 2019

Keywords:

Lake Qarun

El-Batts

El-Wadi Drains

Water quality index

Microbial assessment

Egypt

\begin{abstract}
This study was carried out on Lake Qarun and 2 drains (El-Batts and El-Wadi) that discharging wastewater into it, at Fayoum Province, Egypt, to assess the Water Quality Index (WQI) and miicrobial load of their waters. This investigation was conducted during the period from autumn 2017 to summer 2018. The general annual averages of WQI values of Lake Water were poor for irrigation (69.61) and very poor for aquatic life (78.53). El-Batts and El-Wadi Drains were poor both for irrigation (55.45) and for aquatic life (54.45). Moreover, total viable bacteria count (TVBC) at $22^{\circ} \mathrm{C}$ ranged between $3 \times 10^{3} \mathrm{CFU} / \mathrm{ml}$ and $450 \times 10^{3} \mathrm{CFU} / \mathrm{ml}$, and the $\mathrm{TVBC}$ at $37^{\circ} \mathrm{C}$ varied from $0.4 \times 10^{3} \mathrm{CFU} / \mathrm{ml}$ to $330 \times 10^{3} \mathrm{CFU} / \mathrm{ml}$. Total coliform (TC) in the range of $0.3 \times 10^{3}-46 \times 10^{3}$ MPN $/ 100 \mathrm{ml}$ water , Fecal coliform (FC) in the range of $3 \times 10^{2}-460 \times 10^{2} \mathrm{MPN} / 100 \mathrm{ml}$ water . Fecal streptococci (FS) in the range of $3 \times 10^{2}-1100 \times 10^{2} \mathrm{MPN} / 100 \mathrm{ml}$ water and the numbers of E.coli fluctuated between $0.1 \times 10^{2}$ and $60 \times 10^{2}$ CFU $/ 100 \mathrm{ml}$ water. The obtained values of physical, chemical and microbial parameters of Lake and drains water were compared with the standard values set by FAO (1994) for irrigation and CCME (2007) for aquatic life. It was found that the values of tested parameters were higher than the recommended standards and this affects the biota in the studied area and is expected to cause healthy problems.
\end{abstract}

\section{INTRODUCTION}

Lakes and reservoirs are major resources as these hold about $90 \%$ of the world's surface freshwater and are the key freshwater resources for agriculture, fisheries, domestic, industrial, recreational, landscape entertainment, and energy production. However, these utilizations depend on the desirable water quality that should be based on a well-balanced environment in terms of its physical, chemical, and biological characteristics. The lentic surface water quality in reservoirs, lakes, or ponds is severely affected by anthropogenic pollution, and many efforts have already been made to assess and manage their water quality.

Information and case studies reviewed in this entry indicate that the lakes and reservoirs are at risk from overexploitation, over enrichment, toxic contamination, and sedimentation.

The entry may inspire future environmental and water resource professionals to take necessary actions to mitigate lake and reservoir pollution (Karmakar and Musthafa, 2013). 
Lake Qarun has many drastic changes that affect the potential economic role as a site for living natural resources. The main reason came from gradually increasing salinity over the last century. The increase in salinity depends on the input of drainage water (controlled by irrigation practices) and the subtropical climate of the lake leading to high temperature and seasonal fluctuations in water evaporation rate (Anwar et al., 2001). The quality and quantity of surface water bodies such as lakes depend upon the climate, catchments, geography of the area and the inputs and outputs both natural and manmade (Gray, 1994). The water quality of lakes can be degraded due to microbiological and chemicals contaminants. The monitoring and assessment of water quality of freshwater lakes such as Lake Qarun in Egypt is therefore imperative because humans, wildlife and aquatic life consume their water (Bronmark and Hansson, 2002). The aquatic environment is subjected to different types of pollutants via intrusion of industrial, agricultural and domestic waste water.

Many factors affecting Lake Qarun ecosystem include the climatic conditions, amount of discharged wastewater, seepage from the surrounding cultivated land and geological aspects (Abdel-Satar et al., 2003). The most of agricultural drainage water reaches the lake by two main drains, El-Batts and El-Wadi, whereas there are minor drains poured its drainage water into the lake by means of hydraulic pumps but in small amounts (Authman and Abbas, 2007).

Coliforms group and Escherichia coli are great importance among bacterial indicators used in water quality definition and health risk (Giannoulis et al., 2005). Presence of pathogens is usually accompanied by the presence of the classic indicators of contamination such as Escherichia coli, Enterococci and other aerobic bacteria. Coliform bacteria have long been used to indicate fecal contamination of water and thus a health hazard.

The fecal streptococci are considered to be alternative indicators of fecal health hazards. Furthermore, classic indicators can be considered as efficient detectors of pathogens in most cases (Schaffter and Parriaux, 2002). The indicator bacteria such as fecal coliforms (FC) and fecal streptococci (FS) are used for assessment of fecal pollution and possible water quality deterioration in fresh water sources is widely used (APHA, 2005). Presence of any strain of E. coli is likely indicative of fecal contamination of water source (Mugnai et al., 2015).

Lake Qarun was previously studied regarding to water quality (Gupta and Abd El-Hamid, 2003; Mansour and Sidky, 2003; Ali and Fishar, 2005; Fathi and Flower, 2005; Mageed, 2005; Authman and Abbas, 2007; Hussein et al., 2008; Dardir and Wali, 2009; Abdel-Satar et al., 2010; Ahdy et al., 2011; Abou El-Gheit and Abdo, 2012; Abdel Wahed et al., 2015; El-Sayed and Mosad, 2017; Soliman et al., 2018).

The increasing pollution of water resources in Lake Qarun and the consequent effects on aquatic environment and human health is an issue of great concern.

Also, the lake is under severe environmental stress. So, this study focuses on the studying of the evaluation of physical and chemical characteristics of Lake Qarun water. Also, calculate the Water Quality Index (WQI) and microbial assessment of Lake Water.

\section{MATERIALS AND METHODS}

\section{Area under investigation}

Lake Qarun is situated between longitudes of $30^{\circ} 24^{\prime}$ and $30^{\circ} 49^{\prime} \mathrm{E}$ and latitudes $29^{\circ} 24^{\prime}$ and $29^{\circ} 33^{\prime} \mathrm{N}$. It is an inland isolated saline water basin of about 40 $\mathrm{km}$ length and $5.7 \mathrm{~km}$ width and its water depth ranges from 1 to $8 \mathrm{~m}$ meters. Its 
surface area is about $215 \mathrm{~km}^{2}$ and has a water volume about $1,100,000000 \mathrm{~m}^{3}$ (Dardir and Wali, 2009; Ahdy et al., 2011). Also, the lake is the third largest lake in Egypt and its water surface elevation is about $(43.7 \mathrm{~m})$. The length of the lake is 42 $\mathrm{km}$, and the width varies between $5 \mathrm{~km}-9.54 \mathrm{~km}$. The water depth varies between 5 $\mathrm{m}$ in the east to $12 \mathrm{~m}$ in the west.

Sampling

Water samples were collected seasonally and taken from the subsurface (about $30 \mathrm{~cm}$ ) at ten stations to cover the whole lake area, in addition to, two samples from El-Batts and El-Wadi Drains. A Ruttner Water Sampler bottle with capacity of $2 \mathrm{~L}$ was used to collect the samples that were kept in well cleaned plastic bottles for chemical analysis, and microbial samples were collected using sterilized glass bottles then, brought to laboratory in an iced insulated container during transport. The locations and names of collection water samples are represented in (Table 1, Fig. 1).

Table 1: Long. and Lat. and names of collection samples in Lake Qarun.

\begin{tabular}{clccc}
\hline \multirow{2}{*}{ Stations } & \multicolumn{1}{c}{ Features of stations } & $\begin{array}{c}\text { Average of } \\
\text { Depth }(\mathbf{m})\end{array}$ & Longitude & Latitude \\
\hline $\mathbf{1}$ & Opposite to El-Bats Drain & 2.00 & $30^{\circ} 48^{\prime} 47.2^{\prime \prime}$ & $29^{\circ} 31^{\prime} 04.1^{\prime \prime}$ \\
$\mathbf{2}$ & Opposite to El-Oprerg & 3.00 & $30^{\circ} 47^{\prime} 23.1^{\prime \prime}$ & $29^{\circ} 28^{\prime} 58.1^{\prime \prime}$ \\
$\mathbf{3}$ & Far North-East of Lake & 4.00 & $30^{\circ} 44^{\prime} 58.1^{\prime \prime}$ & $29^{\circ} 30^{\prime} 56.5^{\prime \prime}$ \\
$\mathbf{4}$ & Opposite to Abou Nema lasn & 5.00 & $30^{\circ} 42^{\prime} 53.9^{\prime \prime}$ & $29^{\circ} 29^{\prime} 11.4^{\prime \prime}$ \\
$\mathbf{5}$ & Hkor Maeiouf (Middle lake) & 5.00 & $30^{\circ} 40^{\prime} 57.4^{\prime \prime}$ & $29^{\circ} 29^{\prime} 37^{\prime \prime}$ \\
$\mathbf{6}$ & North of El-Karn Island (Middle lake) & 7.50 & $30^{\circ} 37^{\prime} 10.9^{\prime \prime}$ & $29^{\circ} 29^{\prime} 36.8^{\prime \prime}$ \\
$\mathbf{7}$ & Opposite to El-Wadi Drain & 2.50 & $30^{\circ} 37^{\prime} 43.4^{\prime \prime}$ & $29^{\circ} 26^{\prime} 49.4^{\prime \prime}$ \\
$\mathbf{8}$ & Opposite to Maser for reconstruction & 5.50 & $30^{\circ} 34^{\prime} 51.3^{\prime \prime}$ & $29^{\circ} 27^{\prime} 41.0^{\prime \prime}$ \\
$\mathbf{9}$ & West Lake & 4.00 & $30^{\circ} 31^{\prime} 09.6^{\prime \prime}$ & $29^{\circ} 25^{\prime} 42.4^{\prime \prime}$ \\
$\mathbf{1 0}$ & Malahet Mizar (Far West of Lake) & 4.00 & $30^{\circ} 26^{\prime} 08.4^{\prime \prime}$ & $29^{\circ} 26^{\prime} 37.1^{\prime \prime}$ \\
$\mathbf{1 1}$ & El-Batts Drain & 1.50 & $30^{\circ} 49^{\prime} 20.8^{\prime \prime}$ & $29^{\circ} 32^{\prime} 52 . .4^{\prime \prime}$ \\
$\mathbf{1 2}$ & El-Wadi Drain & 1.50 & $30^{\circ} 38^{\prime} 08.4^{\prime \prime}$ & $29^{\circ} 30^{\prime} 23.5^{\prime \prime}$ \\
\hline
\end{tabular}

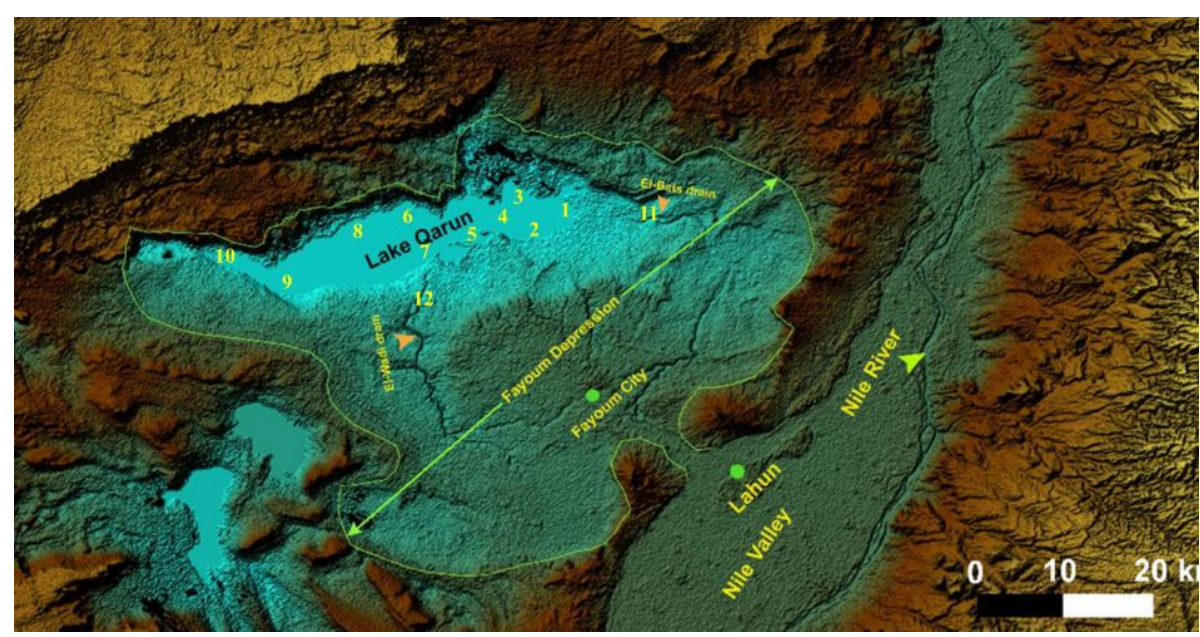

Fig. 1: Map of collection water samples locations in Lake Qarun.

\section{Physical and chemical analyses}

Physical, chemical and microbial analyses of water samples were done according to the methods described in American Public Health Association (APHA, 2005). Water temperature $\left({ }^{\circ} \mathrm{C}\right), \mathrm{pH}$ and electrical conductivity $(\mathrm{EC}, \mathrm{mS} / \mathrm{cm})$ were insitu measured using Hydrolab model Multi Set 430i WTW. Transparency and depth were measured using a white/black Secchi Disk $(20 \mathrm{~cm}$ in diameter). Total solids 
(TS) were measured by evaporating a known volume of well mixed sample. A total dissolved solid (TDS) was determined by filtering a volume of sample through a glass fiber filter (GF/C), and a known volume of filtrate was evaporated at $105^{\circ} \mathrm{C}$. Total suspended solids (TSS) equal the difference between TS and TDS. Dissolved oxygen (DO, mg/L) was assayed using a modified Winkler method. Biological oxygen demand (BOD) was determined by using the 5 days incubation method. Chemical oxygen demand (COD) was carried out using the potassium permanganate method. Water alkalinity was determined immediately after sampling collection using phenolphthalein and methyl orange indicators. Chlorisity was measured using Mohr's method and Sulfate by turbidimetric methods. Calcium and magnesium were detected by using a complexemetry method by direct titration using EDTA solution. Sodium $(\mathrm{Na})$ and potassium $(\mathrm{K})$ were measured using Flame Atomic Absorption Spectrophotometer (FAAS) Model JENWAY PFP.7 U.K. Ammonia was determined by the phenate method. Nitrite was determined using a colorimetric method with formation of a reddish purple azo-dye. Nitrate was measured as nitrite after cadmium reduction. Orthophosphate and total phosphorus (TP) were estimated by using the ascorbic acid-molybdate method. Reactive silicate was determined using the molybdate method.

Microbial analysis

\section{Total Viable Bacterial Count (TVBC)}

Pour plate method was used for enumeration of total bacterial counts at $22^{\circ} \mathrm{C}$ and $37^{\circ} \mathrm{C}$ using plate count agar media containing (g/1): tryptone, 5.0; glucose, 1.0; yeast extract, 2.5; agar, 15; and $\mathrm{pH}$ adjusted at 6.8 0.2 .

\section{Estimation of Total Coliforms (TC) and Fecal Coliforms (FC)}

Numbers of total coliforms and fecal coliforms were determined using most probable number (MPN) technique; three dilutions of each sample were used, three replicates tubes containing MacConkey broth media are containing $(\mathrm{g} / \mathrm{l})$ : peptone, 20.0; $\mathrm{NaCl}, 5.0$; lactose, 5.0; sodium taurocholate, 5.0; bromocresole purple, 0.01 and $\mathrm{pH}$ adjusted at $6.8 \pm 0.2$. Double and single strengths were used for $10,1.0$ and $0.1 \mathrm{~mL}$, respectively. All tubes were provided with Durham fermentation tubes. The inoculated tubes were incubated at $35 \pm 0.5{ }^{0} \mathrm{C}$ for $48 \mathrm{hr}$. and at $44.5{ }^{0} \mathrm{C}$ (in water bath) for $24 \mathrm{hr}$. for fecal coliforms. Acid and gas formation refer to positive result. The positive tubes were streaked on the Eosin Methylene Blue (EMB) agar plates using sterile loop and incubated at $37{ }^{0} \mathrm{C}$ for $24 \mathrm{hr}$. and microscopic examination was take place as confirmatory test.

\section{Estimation of Fecal streptococci (FS)}

Azide dextrose broth media are containing $(\mathrm{g} / \mathrm{l})$ : peptone, 15.0; beef extract, 4.5; $\mathrm{NaCl}, 7.5$; sodium azide, 0.25 and $\mathrm{pH}$ adjusted at $6.8 \pm 0.2$, double and single strengths were used, all tubes were inoculated and incubated at $35 \pm 0.5{ }^{0} \mathrm{C}$ for $48 \mathrm{~h}$. Positive results scored as turbidity due to the growth of Streptococci group.

\section{Estimation of Escherichia coli}

By membrane filtration method, water samples were filtrate using filter paper $(0.45 \mu \mathrm{m}$ pore size) to trapping bacterial cell and the filter carefully transferred into Eosin Methylene Blue agar media are containing (g/l): peptone, 10.0; lactose, 10.0; $\mathrm{K}_{2} \mathrm{HPO}_{4}, 2.0$; eosin $\mathrm{Y}, 0.4$; methylene blue, 0.065; agar, 15; finally $\mathrm{pH}$ adjusted at $6.8 \pm 0.2$. The plates were incubated at $44.5{ }^{0} \mathrm{C}$ for $24 \mathrm{~h}$. After incubation the membrane filters were examined for typical colonies; $2-3 \mathrm{~mm}$ in diameter, smooth with entire edge and green metallic sheen. Colonies were counted.

\section{Water quality index}


Water quality index (WQI) is defined as a technique of rating that provides the composite influence of individual water quality parameter on the overall quality of water (Al-Mohammed and Mutasher, 2013). The calculation method of WQI was developed by Brown et al., (1972), which has been widely used by many scientists (Balan et al., 2012; Chowdhury et al., 2012 and Tyagi et al., 2013). The mathematical formula of this WQI method is given by:

$$
\mathrm{WQI}=\frac{\sum_{i=1}^{n} Q i W i}{\sum_{i=1}^{n} W i}
$$

Where Qi is the sub quality index of $i^{\text {th }}$ parameter (or Qi is the quality rating scale of each parameter). $\mathrm{W}=$ weight unit of each parameter, $\mathrm{n}=$ number of parameters.

Calculation of Qi value

$$
\mathrm{Qi}=\frac{(V i-V o)}{(S i-V o)}
$$

$\mathrm{Vi}=$ measured value of $\mathrm{i}^{\text {th }}$ parameter, $\mathrm{Si}=$ standard permissible value of $\mathrm{i}^{\text {th }}$ parameter, Vo $=$ ideal value of $i^{\text {th }}$ parameter in pure water, $V_{0}=$ zero for all parameters except for $\mathrm{pH}=7.0$ and $\mathrm{DO}=14.6 \mathrm{mg} / \mathrm{l}$ (Tripaty and Sahu, 2005).

\section{Calculation of Wi value}

Calculation of unit weight (Wi) for various water quality parameters is inversely proportional to the recommended standards for the corresponding parameters.

$$
\text { Wi } \alpha \frac{1}{\mathrm{Si}} \text { Or } \mathrm{Wi}=\frac{\mathrm{K}}{\mathrm{Si}}
$$

Where $\mathrm{K}$ is the proportionality constant of the "Weights" for various water quality characteristics:

$$
\mathrm{K}=\frac{1}{\sum_{i=1}^{n} \frac{1}{\mathrm{Si}}}
$$

WQI has been classified into 5 classes, the water quality is rated excellent, good, poor, very poor and unfit when the value of the index lies between 0.00-25, 26$50,51-75,76-100$ and $>100$, respectively, according to the values shown on (Table 2).

Table 2: Water Quality Rating (WQR) as weight arithmetic WQI method

\begin{tabular}{lll}
\hline WQI value & Water Quality Rating (WQR) & Grading \\
\hline $\mathbf{0 - 2 5}$ & Excellent & $\mathrm{A}$ \\
$\mathbf{2 6 - 5 0}$ & Good & $\mathrm{B}$ \\
$\mathbf{5 1 - 7 5}$ & Poor & $\mathrm{C}$ \\
$\mathbf{7 6 - 1 0 0}$ & Very Poor & $\mathrm{D}$ \\
Above 100 & Unsuitable for drinking purpose & E \\
\hline
\end{tabular}

\section{RESULTS AND DISCUSSION}

\section{Water Quality Monitoring}

Water quality monitoring refers to the acquisition of quantitative and representative information on the physical, chemical, and biological characteristics of a water body over time and space (Sanders et al., 1983). The impact and behavior of contaminants in an aquatic ecosystem is complex and may involve adsorptiondesorption, precipitation-solubilization, filtration, biological uptake, excretion, and sedimentation-suspension. Besides natural processes affecting water quality, there are also anthropogenic impacts, such as man-induced point and non-point sources, 
xenobiotic, and alteration of water quality due to unwise water use and river engineering projects (e.g., irrigation, damming, etc.).

\section{Temperatre}

The water temperature of Lake Qarun water incresed during summer season and was found to be $27.40{ }^{\circ} \mathrm{C}$ and the lowest temperature recorded was $14.30{ }^{\circ} \mathrm{C}$ during winter season and the general average was $20.66{ }^{\circ} \mathrm{C}$. The drains water temperature ranged between $15.10-27.40{ }^{\circ} \mathrm{C}$. There is no clear thermal stratified recorded in the lake due to shallowness of the lake ( $\sim 4 \mathrm{~m}$ depth in average) and it is considered being homoeothermic in nature. This result agree with that reported by Mageed, (2005) and Authman and Abbas, (2007). The water temperature values showed the expected seasonal pattern with no differences between the sampling stations, coincident with that reported by Kagalou et al., (2001) and Sivri et al., (2007).

\section{Transparency and Depthes}

The changes in water transparency values ranged from 20 to $150 \mathrm{~cm}$ with a general average of $55.20 \mathrm{~cm}$ in the lake water. The maximum value was found at site 10 during spring season and the lowest was found at site 1 during winter season. This may be due to; the discharging drainage water from the drains in the eastern and middle sections is loaded with suspended particles led to decreasing transparency compared with the western part. For drains water was ranged between $10.00-$ $100.00 \mathrm{~cm}$. The low observed transparency could be attributed to the effect of fertilizers and feed used in fish farming, the disposal of untreated sewage and agricultural effluents into the two drains. These results are agreed with that reported by Abdel-Satar et al., (2010). The changes in depth values of Lake ranged from 2.0 to $7.50 \mathrm{~m}$, with a general average of $4.25 \mathrm{~m}$. The maximum value of depth was found at site 6 and lower was at site 1. For drains was found to be in the ranges of $150-$ $160 \mathrm{~cm}$.

\section{Electrical conductivity (EC)}

EC at drains were fluctuated between $1.97-2.48$ and $2.45-3.20 \mathrm{mS} / \mathrm{cm}$, with overall mean value $2.56 \mathrm{mS} / \mathrm{cm}$, but EC at Lake Qarun water were fluctuated between $11.20-53.60 \mathrm{mS} / \mathrm{cm}$, with overall mean value $43.60 \mathrm{mS} / \mathrm{cm}$. The lowest value of EC was recorded at site 1 opposite to El-Batts drain. While the maximum values were found at site 10 in summer. The increasing in EC values of lake Qarun during summer may be attributed to the decreasing in the water level as a result of high evaporation rate and lowering the amount of drainage water pour into the Lake. On the other side the lower values were recorded durin winter may be due to the direct effect of dilution by drainage water especially areas facing the drians. This is in agreement with that reported by Authman and Abbas, (2007).

\section{Solids (TS, TDS and TSS):}

TS, TDS and TSS values found in the ranges of 23.05-48.41, 18.79-36.68 and 1.14-15.51 g/l, and the mean values were 39.27, 32.44 and $6.94 \mathrm{~g} / \mathrm{l}$, respectively. For El-Batts and El-Wadi drains they ranged between 2.13-4.32, 1.01-2.93 and 0.22-2.18 $\mathrm{g} / \mathrm{l}$, respectively. The increasing in (TS, TDS and TSS) values during summer season, may be attributed to the high evaporation rate while their decrease during cold seasons may be attributed to the dilution effect and raising of the water level in the lake through the drainage water discharging by the two drains during these seasons. These results are agree with that reported by Authman and Abbas, (2007). 


\section{The pH Values}

The favorable range of $\mathrm{pH}$ is $6.5-9.0$ are most suitable for fish production (Lloyd, 1992). $\mathrm{pH}$ values of Lake water are quite variable throughout the seasons and $\mathrm{pH}>7$ indicates that alkaline water conditions are dominant in the Lake. $\mathrm{pH}$ values were found in the permissible limits and ranged between $7.29-8.84$. The high value in autumn season at site 4 , while lowest value in winter season at site 1 , with an overall average value of 8.29. For drains were ranged between $7.47-8.84$, Table (3 and 4). The $\mathrm{pH}$ values of two drains water were found in the same ranges of lake water.

\section{Oxygen (DO, COD and BOD)}

The concentration values of DO and COD were found in the ranges of 3.84 12.80 and $7.04-17.52 \mathrm{mg} / \mathrm{l}$ and the general annual average concentrations were 7.57 and $12.85 \mathrm{mg} / \mathrm{l}$, respectively; while drains were recorded 4.13-10.96 and 2.28 - 9.77 $\mathrm{mg} / \mathrm{l}$, respectively. The highest value of BOD in Lake Qarun was $11.80 \mathrm{mg} / \mathrm{l}$ at site 4 in autumn season which points out significant entry of organic pollution load to the lake, while drainage water was $10.84 \mathrm{mg} / \mathrm{l}$ at El-Wadi drain in spring.

Table 3: Analytical results of Lake Qarun water

\begin{tabular}{|c|c|c|c|c|c|c|}
\hline \multirow[b]{2}{*}{ Parameters } & \multirow{2}{*}{ Mean } & \multirow[b]{2}{*}{ SD } & \multirow[b]{2}{*}{ Min } & \multirow[b]{2}{*}{$\operatorname{Max}$} & \multicolumn{2}{|c|}{ Guideline } \\
\hline & & & & & $\begin{array}{c}\text { Irrigation } \\
(\text { FAO, 1994) }\end{array}$ & $\begin{array}{c}\text { Aquatic life } \\
\text { (CCME, 2007) }\end{array}$ \\
\hline Water temp. ${ }^{0} \mathrm{C}$ & 20.66 & 4.66 & 14.30 & 27.40 & & $8-28$ \\
\hline TS $(g / 1)$ & 39.27 & 4.93 & 23.05 & 48.41 & & \\
\hline TDS (g/l) & 32.44 & 3.56 & 18.79 & 36.68 & 2 & 0.5 \\
\hline TSS (g/l) & 6.94 & 3.01 & 1.14 & 15.51 & & +0.025 \\
\hline Trans. $(\mathrm{cm})$ & 55.20 & 27.19 & 20.0 & 150.0 & & \\
\hline Depth (m) & 4.25 & 1.60 & 2 & 7.50 & & \\
\hline $\mathrm{EC}(\mathrm{mS} / \mathrm{cm})$ & 43.60 & 10.13 & 11.20 & 53.80 & 3 & \\
\hline $\mathrm{pH}$ & 8.29 & 0.29 & 7.29 & 8.84 & 8.5 & $6.5-9.0$ \\
\hline $\mathrm{DO}(\mathrm{mg} / \mathrm{l})$ & 7.57 & 1.76 & 3.84 & 12.80 & & 5.5 \\
\hline $\mathrm{BOD}(\mathrm{mg} / \mathrm{l})$ & 5.93 & 1.95 & 2.33 & 11.8 & & 5 \\
\hline $\mathrm{COD}(\mathrm{mg} / \mathrm{l})$ & 12.85 & 2.88 & 7.04 & 17.52 & & 7 \\
\hline $\mathrm{CO}_{3}^{--}(\mathrm{mg} / \mathrm{l})$ & 27.28 & 17.45 & 0 & 91.5 & 3 & \\
\hline $\mathrm{HCO}_{3}^{-}(\mathrm{mg} / \mathrm{l})$ & 202.95 & 53.80 & 135.0 & 343.0 & 610 & \\
\hline T-Alkalinity & 230.23 & 53.87 & 165.0 & 343.0 & & \\
\hline $\mathrm{NO}_{2}-\mathrm{N}(\mu \mathrm{g} / \mathrm{l})$ & 33.62 & 66.52 & 4.64 & 416.14 & & 0.06 \\
\hline $\mathrm{NO}_{3}{ }^{-}-\mathrm{N}(\mu \mathrm{g} / \mathrm{l})$ & 86.86 & 113.69 & 4.56 & 635.99 & 10 & 2.93 \\
\hline $\mathrm{NH}_{3}-\mathrm{N}(\mu \mathrm{g} / \mathrm{l})$ & 281.96 & 166.30 & 53.06 & 766.52 & 5 & 1.37 \\
\hline $\mathrm{SO}_{4}^{2-}(\mathrm{g} / \mathrm{l})$ & 7.15 & 3.33 & 2.37 & 13.05 & 0.96 & \\
\hline $\mathrm{SiO}_{2}^{-}(\mathrm{mg} / \mathrm{l})$ & 11.05 & 3.62 & 5.17 & 20.61 & & \\
\hline $\mathrm{PO}_{4}{ }^{3-}(\mu \mathrm{g} / \mathrm{l})$ & 169.29 & 128.75 & 6.02 & 454.69 & 2 & \\
\hline $\mathrm{TP}(\mu \mathrm{g} / \mathrm{l})$ & 308.67 & 198.07 & 50.30 & 968.44 & & \\
\hline $\mathrm{Cl}^{-}(\mathrm{g} / \mathrm{l})$ & 14.76 & 2.62 & 6.38 & 20.28 & 1.063 & 0.12 \\
\hline $\mathrm{Ca}^{2+}(\mathrm{mg} / \mathrm{l})$ & 597.22 & 284.42 & 184.37 & 1458.91 & 400 & \\
\hline $\mathrm{Mg}^{2+}(\mathrm{mg} / \mathrm{l})$ & 1537.95 & 623.06 & 678.53 & 3477.76 & 60 & \\
\hline T- Hardness (g/l) & 7.82 & 3.07 & 3.25 & 17.47 & & \\
\hline $\mathrm{Na}^{+}(\mathrm{g} / \mathrm{l})$ & 9.65 & 2.44 & 3.08 & 15.66 & 0.919 & \\
\hline $\mathrm{K}^{+}(\mathrm{g} / \mathrm{l})$ & 0.53 & 0.31 & 0.10 & 2.04 & 0.002 & \\
\hline TVBC at $22^{\circ} \mathrm{C}\left(\mathrm{CFU} \mathrm{ml} \mathrm{l}^{-1}\right)$ & $67.8 \times 10^{5}$ & $91.7 \times 10^{5}$ & $3 \times 10^{5}$ & $450 \times 10^{5}$ & & \\
\hline TVBC at $37^{\circ} \mathrm{C}\left(\mathrm{CFU} \mathrm{ml} \mathrm{l}^{-1}\right)$ & $68.9 \times 10^{5}$ & $85.7 \times 10^{5}$ & $0.4 \times 10^{5}$ & $330 \times 10^{5}$ & & \\
\hline TC (MPN/ 100ml) & $11 \times 10^{4}$ & $13.9 \times 10^{4}$ & $0.3 \times 10^{4}$ & $46 \times 10^{4}$ & $\begin{array}{c}\text { Unrestricted } \\
\text { irrigation } \\
\leq 10^{3}(\mathrm{WHO} \\
2006)\end{array}$ & \\
\hline FC (MPN/ 100ml) & $53.8 \times 10^{3}$ & $100.6 \times 10^{3}$ & $3 \times 10^{3}$ & $460 \times 10^{3}$ & 100 & \\
\hline FS (MPN/ 100ml) & $128.8 \times 10^{3}$ & $243.9 \times 10^{3}$ & $3 \times 10^{3}$ & $1100 \times 10^{3}$ & & \\
\hline E.coli $(\mathrm{CFU} / 100 \mathrm{ml})$ & $15.5 \times 10^{2}$ & $18.9 \times 10^{2}$ & $0.1 \times 10^{2}$ & $69 \times 10^{2}$ & & \\
\hline
\end{tabular}


Table 4: Analytical results of El-Batts and El-Wadi drainage water drains

\begin{tabular}{|c|c|c|c|c|c|c|}
\hline \multirow[b]{2}{*}{ Parameters } & \multirow[b]{2}{*}{ Mean } & \multirow[b]{2}{*}{ SD } & \multirow[b]{2}{*}{ Min } & \multirow[b]{2}{*}{$\operatorname{Max}$} & \multicolumn{2}{|c|}{ Guideline } \\
\hline & & & & & $\begin{array}{c}\text { Irrigation } \\
(\text { FAO, 1994) }\end{array}$ & $\begin{array}{c}\text { Aquatic life } \\
\text { (CCME, } \\
\text { 2007) }\end{array}$ \\
\hline Water temp. ${ }^{0} \mathrm{C}$ & 22.29 & 4.95 & 15.10 & 27.40 & & $8-28$ \\
\hline TS $(\mathrm{g} / \mathrm{l})$ & 2.84 & 0.91 & 2.13 & 4.32 & & \\
\hline TDS (g/l) & 1.97 & 0.63 & 1.01 & 2.93 & 2 & 0.5 \\
\hline TSS (g/l) & 0.87 & 0.73 & 0.22 & 2.18 & & +0.025 \\
\hline Trans. (cm) & 25.63 & 30.41 & 10.0 & 100.0 & & \\
\hline Depth (m) & 1.55 & 0.07 & 150 & 160.0 & & \\
\hline $\mathrm{EC}(\mathrm{mS} / \mathrm{cm})$ & 2.56 & 0.48 & 1.97 & 3.20 & 3 & \\
\hline $\mathrm{pH}$ & 7.89 & 0.42 & 7.47 & 8.84 & 8.5 & $6.5-9.0$ \\
\hline DO (mg/l) & 6.44 & 2.33 & 4.13 & 10.96 & & 5.5 \\
\hline $\mathrm{BOD}(\mathrm{mg} / \mathrm{l})$ & 3.13 & 3.48 & 0.53 & 10.84 & & 5 \\
\hline $\mathrm{COD}(\mathrm{mg} / \mathrm{l})$ & 5.20 & 2.37 & 2.28 & 9.77 & & 7 \\
\hline $\mathrm{CO}_{3}^{--}(\mathrm{mg} / \mathrm{l})$ & 11.56 & 15.72 & 0.0 & 42.0 & 3 & \\
\hline $\mathrm{HCO}_{3}^{-}(\mathrm{mg} / \mathrm{l})$ & 238.75 & 51.03 & 161.50 & 325.0 & 610 & \\
\hline T-Alkalinity & 250.31 & 50.09 & 163.50 & 325.0 & & \\
\hline $\mathrm{NO}_{2}{ }^{-} \mathrm{N}(\mu \mathrm{g} / \mathrm{l})$ & 327.52 & 263.94 & 9.90 & 723.09 & & 0.06 \\
\hline $\mathrm{NO}_{3}{ }^{-}-\mathrm{N}(\mu \mathrm{g} / \mathrm{l})$ & 186.35 & 152.54 & 47.44 & 441.75 & 10 & 2.93 \\
\hline $\mathrm{NH}_{3}-\mathrm{N}(\mu \mathrm{g} / \mathrm{l})$ & 2410.74 & 1470.69 & 179.84 & 4579.96 & 5 & 1.37 \\
\hline $\mathrm{SO}_{4}^{2-}(\mathrm{g} / \mathrm{l})$ & 3.17 & 3.00 & 0.58 & 8.70 & 0.96 & \\
\hline $\mathrm{SiO}_{2}^{-}(\mathrm{mg} / \mathrm{l})$ & 10.0 & 4.43 & 4.22 & 16.76 & & \\
\hline $\mathrm{PO}_{4}{ }^{3-}(\mu \mathrm{g} / \mathrm{l})$ & 390.98 & 140.55 & 262.35 & 627.74 & 2000 & \\
\hline $\mathrm{TP}(\mu \mathrm{g} / \mathrm{l})$ & 698.18 & 249.62 & 302.18 & 1097.42 & & \\
\hline $\mathrm{Cl}^{-}(\mathrm{g} / \mathrm{l})$ & 1.23 & 0.29 & 0.71 & 1.72 & 1.063 & 0.12 \\
\hline $\mathrm{Ca}^{2+}(\mathrm{mg} / \mathrm{l})$ & 361.22 & 258.78 & 116.23 & 745.49 & 400 & \\
\hline $\mathrm{Mg}^{2+}(\mathrm{mg} / \mathrm{l})$ & 907.74 & 657.98 & 167.81 & 2130.43 & 60 & \\
\hline T- Hardness (g/l) & 4.64 & 3.31 & 1.07 & 10.63 & & \\
\hline $\mathrm{Na}^{+}(\mathrm{g} / \mathrm{l})$ & 2.30 & 2.75 & 0.70 & 8.91 & 0.919 & \\
\hline $\mathrm{K}^{+}(\mathrm{g} / \mathrm{l})$ & 0.52 & 0.77 & 0.02 & 1.78 & 0.002 & \\
\hline TVBC at $22^{\circ} \mathrm{C}\left(\mathrm{CFU} \mathrm{ml} \mathrm{m}^{-1}\right)$ & $39.3 \times 10^{5}$ & $22.7 \times 10^{5}$ & $15 \times 10^{5}$ & $90 \times 10^{5}$ & & \\
\hline $\mathrm{TVBC}$ at $37^{\circ} \mathrm{C}\left(\mathrm{CFU} \mathrm{ml}{ }^{-1}\right)$ & $236 \times 10^{5}$ & $105.02 \times 10^{5}$ & $145 \times 10^{5}$ & $460 \times 10^{5}$ & & \\
\hline TC (MPN/ 100ml) & $46 \times 10^{4}$ & $31.56 \times 10^{4}$ & $11 \times 10^{4}$ & $93 \times 10^{4}$ & $\begin{array}{c}\text { Unrestricted } \\
\text { irrigation } \\
\leq 10^{3}(\mathrm{WHO}, 2006)\end{array}$ & \\
\hline FC (MPN/ 100ml) & $40 \times 10^{3}$ & $27.34 \times 10^{3}$ & $11 \times 10^{3}$ & $93 \times 10^{3}$ & 100 & \\
\hline FS (MPN/ 100ml) & $201.6 \times 10^{3}$ & $169.9 \times 10^{3}$ & $53 \times 10^{3}$ & $460 \times 10^{3}$ & & \\
\hline E.coli $(\mathrm{CFU} / 100 \mathrm{ml})$ & $74.5 \times 10^{2}$ & $19.20 \times 10^{2}$ & $48 \times 10^{2}$ & $98 \times 10^{2}$ & & \\
\hline
\end{tabular}

The highest value of DO $12.80 \mathrm{mg} / \mathrm{l}$ was recorded during winter, which could be mainly attributed to the decrease in temperature, prevailing winds action which permits the increase in solubility of atmospheric oxygen gas. The DO values showed relative decrease during summer was reached $3.84 \mathrm{mg} / \mathrm{l}$ which is mainly attributed to elevation of water temperature which lead to decrease in solubility of oxygen gas. In addition to, the oxidation of organic matter by the microorganisms consuming part of dissolved oxygen. These results agreed with that reported by Sabae and Mohamed, (2015); Al-Afify et al., (2018). Generally, the higher values of DO, BOD and COD are indications on higher microbial activities. This was reflected on somewhat elevated values of $\mathrm{NH}_{4}^{+}, \mathrm{NO}_{2}^{-}$and $\mathrm{NO}_{3}^{-}$.

\section{COD/BOD ratio}

Concerning the biodegradability condition of the aquatic body of the area under investigation the ratio $\mathrm{BOD} / \mathrm{COD}$ were taken into consideration. This ratio in the order 1:1 is characteristic of the purified water according to the national standard and the ratio 2:1 to $4: 1$ is specific crude domestic sewage (Anon, 1997). Also, the high ratio of COD/BOD points out excessive quantity of organic matter which is not decomposed by microorganisms. COD/BOD ratios of lake water ranged between $1.07-5.32$ and its annual average 2.40, while drainage water was $0.59-13.51$, and its annual average was 4.21. These closer values also show that the structures of organic matter entering to Lake Qarun were similar approximately in all station except the locations 1 and 7 (in front of El-Wadi and El-Batts drains). 


\section{Major Anions $\left(\mathrm{CO}_{3}^{-2}, \mathrm{HCO}_{3}^{-}, \mathrm{Cl}^{-}\right.$and $\left.\mathrm{SO}_{4}{ }^{-2}\right)$}

The carbonate and bicarbonate are the major components of alkalinity of surface water. $\mathrm{CO}_{3}{ }^{-2}$ and $\mathrm{HCO}_{3}{ }^{-}$concentrations were found in the ranges of 0.00 91.50 and $135.00-343.00 \mathrm{mg} / \mathrm{l}$. While drainage water were $0.00-42.00$ and $161.50-$ $325.00 \mathrm{mg} / \mathrm{l}$, respectively. The increase in bicarbonate during autumn may be attributed to the decrease in water and air temperatures led to the precipitation of calcium bicarbonate. On the other side, the high concentration values during summer with maximum annual average of $267.08 \mathrm{mg} / \mathrm{l}$ may be related to the decomposition of organic matter and/or enhancing the anaerobic processes which increases carbon dioxide in the water column (Elewa, 1993).

The highest value of $\mathrm{Cl}^{-} 20.28 \mathrm{~g} / \mathrm{l}$ was recorded during spring season while the lowest value of $6.38 \mathrm{~g} / \mathrm{l}$ was recorded during autumn season. This may be attributed to the impacts of salt marches adjacent to the Lake, the seepage of salts from the adjacent cultivated lands and underground water. Furthermore, the high rate of evaporation during hot season (spring and summer) and low water level of the lake; as well as, the decrease in the discharged runoff; regard the main reason for increase in the $\mathrm{Cl}^{-}$content. These results agree with that reported by Ali and Fishar, (2005); Authman and Abbas, (2007). For drainage water were $0.71-1.72 \mathrm{~g} / \mathrm{l}$. The $\mathrm{SO}_{4}{ }^{2-}$ values were fluctuated in the ranges of $5.17-20.61 \mathrm{~g} / \mathrm{l}$ for Lake Qarun water, while drainage water (El-Batts and El-Wadi) were $0.58-8.70 \mathrm{~g} / \mathrm{l}$. As whole, the distribution of major anions $\left(\mathrm{Cl}^{-}\right.$and $\left.\mathrm{SO}_{4}{ }^{2-}\right)$ in lake water may be governed mainly by the evaporation rate, the intrusion of drainage water and consumption of lake salts by the Egyptian company of salt and minerals (EMISAL) (Abdel-Satar et al., 2010).

\section{Major Cations $\left(\mathrm{Na}^{+}, \mathrm{K}^{+}, \mathrm{Ca}^{2+}\right.$ and $\left.\mathrm{Mg}^{2+}\right)$}

$\mathrm{Na}^{+}, \mathrm{K}^{+}, \mathrm{Ca}^{2+}$ and $\mathrm{Mg}^{2+}$ concentrations of Lake water were found in the ranges of 3.08-15.66, $0.10-2.04,0.18-1.46$ and $0.69-3.48 \mathrm{~g} / \mathrm{l}$ respectively, and drainage water were $0.70-8.91,0.02-1.78,0.12-0.75$ and $0.17-2.13 \mathrm{~g} / \mathrm{l}$ respectively. In Lake Qarun water, the predominant cation trend was in the order of $\mathrm{Na}^{+}>\mathrm{K}^{+}>\mathrm{Mg}^{2+}$ $>\mathrm{Ca}^{2+}$ with sodium being dominant cation and the predominant anion trend was in the order of $\mathrm{Cl}^{-}>\mathrm{SO}_{4}{ }^{2-}>\mathrm{HCO}_{3}{ }^{-}>\mathrm{CO}_{3}{ }^{-2}$, with chloride being the dominant anion. These results are in agreement with that reported by (Abdel-Satar et al., 2010; Abou El-Gheit and Abdo, 2012).

\section{Nutrient salts}

Nutrient salts $\left(\mathrm{NO}_{2}{ }^{-}, \mathrm{NO}_{3}{ }^{-}, \mathrm{NH}_{3}, \mathrm{PO}_{4}^{-3}\right.$, T.P and $\left.\mathrm{SiO}_{2}{ }^{-}\right)$are plays an important roles in the productivity of the aquatic ecosystems supporting the food chain for phyto and zooplanktons as well as fish (Abdo, 2004). Nitrite is an intermediate product of the aerobic nitrification bacterial process, produced by the autotrophic Nitrosomonas bacteria combining oxygen and ammonia (Bhatnagar and Devi, 2013). Nitrate $\left(\mathrm{NO}_{3}{ }^{-} \mathrm{N}\right)$ can get into water directly as the result of runoff of fertilizers. The concentration levels of $\mathrm{NO}_{2}{ }^{-}, \mathrm{NO}_{3}{ }^{-}$and $\mathrm{NH}_{3}{ }^{-}$were found in the ranges of $4.64-$ $416.14,4.56$ - 635.99 and 53.06-766.52 $\mu \mathrm{g} / \mathrm{l}$, and drainage water were 9.90 - 723.09, 47.44 - 441.75 and $179.84-4579.96 \mu \mathrm{g} / \mathrm{l}$; respectively. These nutrients increase with runoff from agricultural lands especially intensively cultivated lands with large inputs of synthetic fertilizers) and urban wastewater, creating eutrophication (Liu et al., 2009).

Phosphorus that enters the aquatic system through anthropogenic sources, e.g. fertilizer-runoff, potentially could be incorporated into either inorganic or organic fraction. Once phosphorus accumulates within a lake, it can cycle through the water column and promote algal blooms indefinitely (Edwards and Withers, 2008). 
The concentrations levels of $\mathrm{PO}_{4}^{-3}$ and TP were found to be in the ranges of $6.02-454.09$ and 50.30 - 968.44 $\mu \mathrm{g} / \mathrm{l}$ and drainage water were 262.35-627.74 and 302.18-1097.42 $\mu \mathrm{g} / \mathrm{l}$, respectively; as shown in Tables (3 and 4). The high ortho and total phosphates concentration levels can be explained on the basis of the high amount of agricultural runoff and domestic sewage inflow from the adjacent cultivated land and the neighboring villages to the drains (Sayed and Abdel-Satar, 2009). The ranges of $\mathrm{SiO}_{3}{ }^{-}$were ranged between $5.17-20.61 \mathrm{mg} / \mathrm{l}$ and drainage water was 3.17-20.61 and $4.22-16.76 \mathrm{mg} / \mathrm{l}$. The high values of silicates is also may relate to the different agricultural effluents that discharged into Lake Qarun from ElWadi and El-Bats drains. Generally, the most probably the contamination delivered by the relevant drains containing industrial wastes (such as paints and ceramic remnants), agricultural wastes (fertilizers and pesticides) and sewage wastes as well as the wastes of the fish farms found in the southern part of the lake (El-Sayed et al., 2015).

\section{Long- Term Variations in Water Quality of Lake Qarun}

Long- term studies on lake Qarun have provided direct clues to the effect of increased the EC and TS values with increase the evaporation rate. In addition to the increased in the concentrations of $\mathrm{Cl}^{-}, \mathrm{Ca}^{2+}, \mathrm{Mg}^{2+}, \mathrm{Na}^{+}$and $\mathrm{K}^{+}$. The mean concentration values of nutrient salts $\left(\mathrm{NO}_{2}^{-}, \mathrm{NO}_{3}^{-}, \mathrm{NH}_{3}, \mathrm{PO}_{4}^{---}\right.$and $\left.\mathrm{TP}\right)$ were found border line between increased/decreased from 2003 till 2017 (Table 5), corresponding to the quality/ quantity of sewage and agricultural wastes discharged from El- Batts and El- Wadi drains into the lake.

Table 5: Long-term changes of physico-chemical parameters in Lake Qarun

\begin{tabular}{|c|c|c|c|c|c|c|c|c|c|c|c|c|}
\hline \multirow{3}{*}{ Parameters } & \multirow{3}{*}{$\begin{array}{l}\text { Mean } \\
\text { (Case } \\
\text { Study) }\end{array}$} & \multicolumn{10}{|c|}{ Lake Qarun } & \multirow{3}{*}{$\begin{array}{c}\text { Average of al } \\
(2003-2016) \\
(1: 10)\end{array}$} \\
\hline & & 2016 & 2015 & 2015 & 2013 & 2012 & 2010 & 2008 & 2005 & 2005 & 2003 & \\
\hline & & 1 & 2 & 3 & 4 & 5 & 6 & 7 & 8 & 9 & 10 & \\
\hline Water temp. ${ }^{0} \mathrm{C}$ & 20.66 & 23.90 & & 29.85 & & 25.62 & & 27.50 & 22.91 & & & 25.96 \\
\hline TS $(g / l)$ & 39.27 & & & & 37.92 & & 38.36 & & & & & 38.14 \\
\hline TDS (g/l) & 32.44 & & 36.04 & & 34.70 & & 35.31 & 37.80 & & 3.45 & 18.80 & 27.68 \\
\hline TSS $(\mathrm{g} / \mathrm{l})$ & 6.94 & & & & 3.22 & & & & & & & 3.22 \\
\hline Trans. (cm) & 55.20 & & & 110.00 & $\mathbf{5 5 . 5 0}$ & 62.50 & 61.00 & & 55.00 & & & 68.80 \\
\hline Depth (m) & 4.25 & & & & & & & & & & & \\
\hline EC (mmohs/cm) & & & & & 40.69 & 39.42 & & & & & & 40.06 \\
\hline $\mathrm{EC}(\mathrm{mS} / \mathrm{cm})$ & 43.60 & & 35.25 & & & & 42.00 & & & & & 38.63 \\
\hline Salinity (\%o) & & & & & 37.67 & & & & & & & 37.67 \\
\hline Salinity $(g / \mathbf{l})$ & & 27.45 & & 27.45 & & & & 25.90 & 32.42 & & & 28.31 \\
\hline pH & 8.29 & 7.91 & 8.22 & 8.35 & 8.10 & 8.48 & 8.23 & & 8.44 & & 7.90 & 8.20 \\
\hline DO (mg/l) & 7.57 & 6.43 & & 5.40 & 8.68 & 10.07 & 9.38 & 8.50 & 7.88 & & 10.00 & 8.29 \\
\hline BOD $(\mathrm{mg} / \mathrm{l})$ & 5.93 & 3.78 & & 4.70 & & & 7.24 & 8.00 & 5.97 & & & 5.94 \\
\hline $\operatorname{COD}(\mathrm{mg} / \mathrm{l})$ & 12.85 & 32.50 & & 14.75 & & & 11.99 & & & & & 19.75 \\
\hline $\mathrm{CO}_{3}^{--}(\mathrm{mg} / \mathrm{l})$ & 27.28 & & & & 16.61 & & 24.21 & & & & 20.00 & 20.27 \\
\hline $\mathrm{HCO}_{3}^{-}(\mathrm{mg} / \mathrm{l})$ & 202.95 & & 172.0 & & 213.06 & & 158.60 & & & & 290.00 & 208.42 \\
\hline T-Alkalinity & 230.23 & & & & 229.67 & 290.83 & & 156.00 & & 142.00 & & 204.63 \\
\hline $\mathrm{NO}_{2}{ }^{-} \mathrm{N}(\mu \mathrm{g} / \mathrm{l})$ & 33.62 & 749.87 & & 19.35 & 12.00 & & 10.09 & 21.00 & 13.77 & & & 137.68 \\
\hline $\mathrm{NO}_{3}-\mathrm{N}(\mu \mathrm{g} / \mathrm{l})$ & 86.86 & 325.30 & 19.50 & 321.40 & 41.00 & & 38.80 & 109.00 & 93.90 & 90.00 & & 129.86 \\
\hline $\mathrm{NH}_{3}-\mathrm{N}(\mu \mathrm{g} / \mathrm{l})$ & 281.96 & 114.30 & & 184.45 & 350.00 & & 379.00 & 340.00 & 163.20 & & & 255.16 \\
\hline $\mathrm{SO}_{4}{ }^{2-}(\mathrm{g} / \mathrm{l})$ & 7.150 & & 11.800 & & 5.30 & & 6.08 & & 8.786 & 8.50 & 5.02 & 7.58 \\
\hline $\mathrm{SiO}_{4}^{-}(\mathrm{mg} / \mathrm{l})$ & 11.05 & 2.79 & 8 & 2.40 & & & 3.56 & & & & & 4.19 \\
\hline $\mathrm{PO}_{4}{ }^{3-}(\mu \mathrm{g} / \mathrm{l})$ & 169.29 & 249.93 & 90 & 30.80 & 92.00 & & 94.02 & & 59.52 & 88.00 & & 100.61 \\
\hline $\mathrm{TP}(\mu \mathrm{g} / \mathrm{l})$ & 308.67 & & & 162.60 & 584.00 & & 586.00 & & & & & 444.20 \\
\hline $\mathrm{Cl}^{-}(\mathrm{g} / \mathrm{l})$ & 14.76 & & 12.054 & & 11.95 & & 12.978 & 14.30 & 13.805 & 15.00 & 6.78 & 12.41 \\
\hline $\mathrm{Ca}^{2+}(\mathrm{mg} / \mathrm{l})$ & 597.22 & & 444 & & 430.00 & & 491.78 & & & 374.00 & 320.00 & 411.96 \\
\hline $\mathrm{Mg}^{2+}(\mathrm{mg} / \mathrm{l})$ & 1537.95 & & 1124 & & 1040.00 & & 1266.98 & & & 108.00 & 680.00 & 843.80 \\
\hline T- Hardness (g/l) & 7.82 & & & & & 14.43 & & 6.19 & & & & 10.31 \\
\hline $\mathrm{Na}^{+}(\mathrm{g} / \mathrm{l})$ & 9.65 & & 10.119 & & 6.40 & & 6.52 & & 9.064 & 7.70 & 5.27 & 7.51 \\
\hline $\mathrm{K}^{+}(\mathrm{g} / \mathrm{l})$ & 0.53 & & 0.319 & & 0.18 & & 0.34 & & 0.364 & 74.20 & & 15.08 \\
\hline
\end{tabular}

1 - Shaaban et al., (2016), 2- Abdel Wahed et al., (2015), 3- El-Shabrawy et al., (2015), 4 - Ibrahim and Ramzy, (2013), 5- Saeed and Mohammed, (2012), 6 - Abdel-Satar et al., (2010), 7- Ali et al., (2008), 8- Fathi and Flower, (2005), 9 - Mageed, (2005), 10 - Mansour and Sidky, (2003).

\section{Microbial characteristics of Lake Qarun and drains}

Microbial assessments at Lake Qarun water are mention at (Table 3) and microbial results for drains (El-Batts drain and El-Wadi drain) are mention at (Table 4). The bacteriological quality of water was usually controlled by certain parameters 
like bacterial density in terms of plate count at $22^{\circ} \mathrm{C}$ and $37^{\circ} \mathrm{C}$ as well as coliforms as indicator of fecal pollution. In addition to the use of fecal streptococci as a parameter for judgment of water pollution tended to give confirmatory information for the quality of water intended for civic use (Sabae, 1999).

Total viable bacterial count (TVBC) counts at Lake Qarun water at $22^{\circ} \mathrm{C}$ ranged between $3 \times 10^{3} \mathrm{CFU} / \mathrm{ml}$ to $450 \times 10^{3} \mathrm{CFU} / \mathrm{ml}$, and $\mathrm{TVBC}$ at $37^{\circ} \mathrm{C}$ varied from $0.4 \times 10^{3} \mathrm{CFU} / \mathrm{ml}$ to $330 \times 10^{3} \mathrm{CFU} / \mathrm{ml}$. The highest value at $22^{\circ} \mathrm{C}$ and at $37^{\circ} \mathrm{C}$ was recorded at station opposite to El-Oprerg. On the other hand, the lowest values at $22^{\circ} \mathrm{C}$ and $37^{\circ} \mathrm{C}$ were recorded at Far North-East of Lake and khor Maeiouf (Middle lake) respectively. These results agree with Ali and Osman, (2010). This may be due to the effect the sunlight (UV ray), organic substances, biological activity and sedimentation (Olayemi, 1993). On the other side, TVBC at drainage water are ranged between $15 \times 10^{5}$ to $90 \times 10^{5} \mathrm{CFU} / \mathrm{ml}$ at $22^{\circ} \mathrm{C}$ and $145 \times 10^{5}$ to $460 \times 10^{5} \mathrm{CFU}$ $/ \mathrm{ml}$ at $37^{\circ} \mathrm{C}$, respectively. The highest value at $22^{\circ} \mathrm{C}$ was recorded in El-Batts drain while the lowest value was recorded at El-Wadi drain. On contrast, the highest values at $37^{\circ} \mathrm{C}$ were recorded at El-Wadi drain while the lowest value was recorded at ElBatts drain. TVBC at $22^{\circ} \mathrm{C}$ and $37^{\circ} \mathrm{C}$ in drains was higher than TVBC in Lake Qarun. The obtained results show high microbial load at drains and subsequently reflected on Lake Qarun. The high load of organic matter in the drainage effluents induced the active multiplication of the bacteria this is in accordance with El-Fadaly et al., (2001) and Sabae, (2004).

Coliforms were internationally recognized in assessing the microbiological quality of water. Total coliform, fecal coliform and fecal streptococci were estimated by most probable number (MPN) technique. Numbers of TC at Lake Qarun were in the range of $\left(0.3 \times 10^{3}-46 \times 10^{3}\right)$. The highest values of TC were recorded at station opposite to El-Batts drain, while the lowest values were recorded at Khor Maeiouf and North of El-Karn Island (Middle Lake). Regional average at Lake Qarun water stations show highest values of (TC) were arranged descending as following: opposite to El-Batts drain, opposite to El-Wadi drain, Malahet Mizar (Far West of Lake), West Lake, Opposite to El-Oprerg, Far North-East of Lake, Khor Maeiouf (Middle lake), Opposite to Abou Nema lasn, North of El-Karn Island (Middle lake) and Opposite to Maser for reconstruction.

Numbers of fecal coliforms (FC) at Lake Qarun were in the range of $3 \times 10^{r}-$ $460 \times 10^{r}$ MPN $/ 100 \mathrm{ml}$. The highest value of fecal coliforms (FC) was recorded at Opposite to El-Batts drain. Numbers of TC at drains were in the range of $11 \times 10^{4}$ $93 \times 10^{4} \mathrm{MPN} / 100 \mathrm{ml}$ water. The highest value of TC was recorded at El-Batts drain. This might be explained by the effect of domestic and agricultural wastes discharge from the urbanized surrounding area (Shaaban-Dessouki et al., 1993). FC at drains was in the range of $11 \times 10^{3}-93 \times 10^{3} \mathrm{MPN} / 100 \mathrm{ml}$ water. The high values of FC might be attributed to the effect of wastewater. The obtained results declare that the stations opposite to El-Batts and El-Wadi drains were recorded high numbers of TC. This might be attributed to the effect of the drains and human activities and pollution effect on bacterial association (Noble et al., 2004).

MPN of fecal coliform bacteria at drains were much higher than Lake Qarun. This indicates the true fact, and the source of pollution at Lake Qarun was the drains, which discharge the drainage water (waste water, agriculture waste). The effects of drains at water quality were findings agreed with those previously reported by Fujioka et al., (1981) and Sabae, (1999).

Numbers of FS at Lake Qarun water were in the range of $3 \times 10^{2}-1100 \times 10^{2}$ MPN/ $100 \mathrm{ml}$ water. FS at drainage water numbers were in the range of $53 \times 10^{3}-$ 
$460 \times 10^{3} \mathrm{MPN} / 100 \mathrm{ml}$ water. The high value of FS was recorded at station opposite to El-Batts drain due to the effect of drainage water which was loaded with agricultural and industrial wastes that affect the cultural condition necessary of bacterial growth as $\mathrm{pH}$ and temperature. High values of TC, FC and FS were detected in Lake Qarun stations, which might be attributed to wastewater discharged into the lake water (Isobe et al., 2004 \& Sabae and Rabeh, 2007) also mention that, the reason of high values in TC, FC and FS was wastewater discharged. US EPA, (2001) reported that the FC / FS ratio indicate the origin of bacterial pollution. FC/FS ratio of 4 or greater indicates a human source. Domestic animals is on average of 0.1 0.6. FC/FS ratio in the present study indicates human, mixed and animal source pollution at Lake Qarun.

Escherichia coli is the best biological water indicator for public health protection because it is present in extremely high numbers in the faeces of all mammals, it does not appreciably multiply in the environment outside its host (Edberg et al., 2000). E. coli at Lake Qarun water were fluctuated between $0.1 \times 10^{2}$ - $60 \times 10^{2} \mathrm{CFU} / 100 \mathrm{ml}$ water. The high value of $E$. coli was recorded at station opposite to El-Batts drain. But $E$. coli at drains were fluctuated between $48 \times 10^{2}-98$ $\times 10^{2} \mathrm{CFU} / 100 \mathrm{ml}$ water.

\section{Water quality index}

Water quality index Table (6) and Fig. (2), illustrate the values of the WQI of Lake Qarun water and two drains (El-Batts and El-Wadi). The WQI score for irrigation water was computed using guidelines of (FAO, 1994). Protection of aquatic life was computed using guidelines of (CCME, 2007). 13 and 7 variables were used for the calculation of WQI according to irrigation and aquatic life criteria, respectively. The selected parameters for irrigation water include, TDS, $\mathrm{pH}, \mathrm{HCO}_{3}{ }^{-}$, $\mathrm{NO}_{2}^{-}-\mathrm{N}, \mathrm{NH}_{3}, \mathrm{PO}_{4}^{-3}, \mathrm{Cl}^{-}, \mathrm{SO}_{4}^{-2}, \mathrm{Na}^{+}, \mathrm{K}^{+}, \mathrm{Ca}^{+2}, \mathrm{Mg}^{+2}$ and fecal coliform. On the other side the aquatic life include TDS, $\mathrm{pH}, \mathrm{DO}, \mathrm{BOD}, \mathrm{COD}, \mathrm{NO}_{3}{ }^{-} \mathrm{N}$ and fecal coliform.

The present results show that the WQI values of Lake Qarun water were ranged between 58.23 - 84.51 and 51.75 - 83.06 with respect to irrigation and aquatic life protection according to the irrigation guidelines and protection of aquatic life guidelines respectively (Table 6).

Table 6: WQI and its categorization of Lake Qarun water for irrigation and aquatic life utilizations.

\begin{tabular}{ccccc}
\hline Stations & \multicolumn{2}{c}{ Irrigation } & \multicolumn{2}{c}{ Aquatic life } \\
& WQI & WQR & WQI & WQR \\
\hline 1 & 58.23 & Good & 73.58 & Poor \\
2 & 64.00 & Poor & 81.71 & Very Poor \\
3 & 59.68 & Poor & 79.83 & Very Poor \\
4 & 72.25 & Poor & 83.06 & Very Poor \\
5 & 84.51 & Very Poor & 79.64 & Very Poor \\
6 & 72.54 & Poor & 79.11 & Very Poor \\
7 & 63.95 & Poor & 69.94 & Poor \\
8 & 73.38 & Poor & 81.22 & Very Poor \\
9 & 74.33 & Poor & 77.46 & Very Poor \\
10 & 73.18 & Poor & 79.44 & Very Poor \\
General Average of Lake & 69.61 & Poor & 78.53 & Very Poor \\
El-Batts Drain & 52.75 & Poor & 56.04 & Poor \\
El-Wadi Drain & 58.44 & Poor & 52.74 & Poor \\
General Average of Drains & 55.45 & Poor & 54.45 & Poor \\
\hline \multicolumn{2}{c}{ WQI = Water Quality Index } & WQR= Water Quality Rating &
\end{tabular}

On the other side the WQI for tow drains (El-Batts and El-Wadi) were recorded 52.75 and 58.44 for irrigation \& 58.44 and 52.74 for aquatic life protection 
respectively. The general annual average value of WQI showed that Lake Qarun water recorded 69.61 (Poor) for irrigation guidelines and 78.53 (Very Poor) for aquatic life guidelines respectively. The general annual average value of WQI for tow drains (El-Batts and El-Wadi) were recorded 55.45 (Poor) for irrigation and 54.45 (Poor) for aquatic life protection respectively. Generally, the water pollution has a negative impact both in terms of water use and ecosystems.

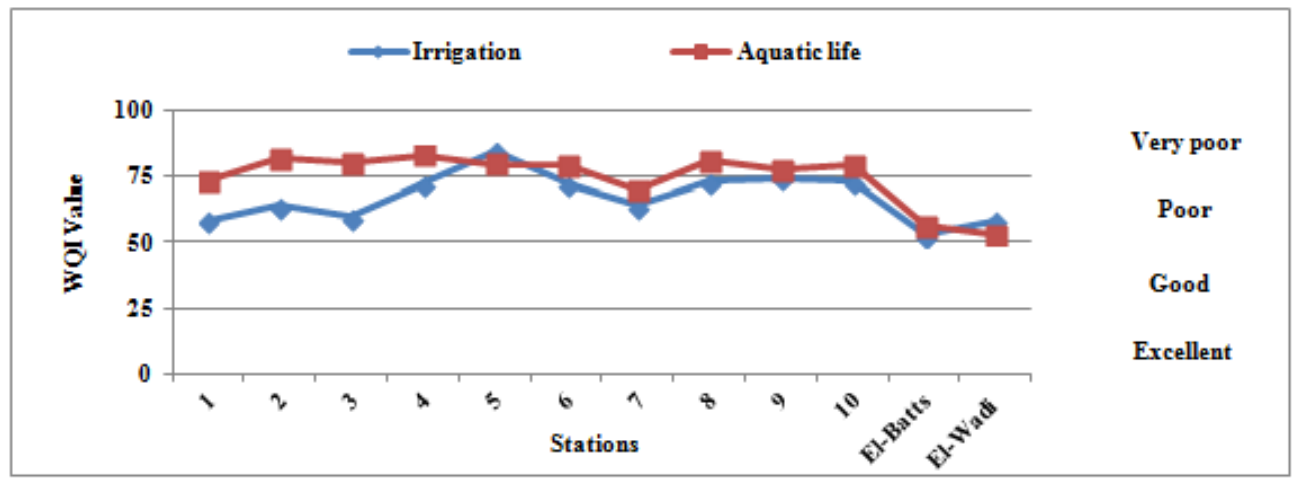

Fig. 2: WQI of Lake Qarun water for irrigation and aquatic life utilizations.

\section{CONCLUSION}

From previous results and discussion we can conclude that municipal and agricultural sewage wastes discharged into Lake Qarun causes serious problem of its water quality. The WQI values revealed that the lake water poor and very poor for irrigation and aquatic life guidelines respectively. The lake water is contaminated by feacal and Escherichia coli which indicate biological pollution. The evaporation rate of Lake Qarun water and climatic conditions are the most important factors affecting physical, chemical and microbiological characteristics.

\section{REFERENCES}

Abdel Wahed, M. S. M.; Mohamed, E. A.; Wolkersdorfer, C.; El-Sayed, MI.; M'nif, A. and Sillanpaa, M.(2015) . Assessment of water quality in surface waters of the Fayoum watershed, Egypt. Environ. Earth. Sci., 74: 1765 - 1783.

Abdel-Satar, A. M.;; Elewa, A. A.; Mekki, A. K. T. and Gohar M. E. (2003). Some Aspects on Trace Elements and Major Cations of Lake Qarun Sediment Egypt. Bull Fac. Sci. Zagazig Univ. Egypt, 25:77 - 97.

Abdel-Satar, A. M.; Goher, M. E. and Sayed, M. F. (2010). Recent environmental changes in water and sediment quality of Lake Qarun, Egypt. J. Fish. Aquat. Sci., 5: $56-69$.

Abdo, M. H. (2004). Environmental studies on the River Nile at Damietta branch region, Egypt. J. Egypt. Acad. Soc. Environ. Develop., (D-Environmental Studies), 5 (2): 85-104.

Abou El-Gheit, E. N.; Abdo M. H. and Mahmoud, S. A. (2012). Impacts of Blooming Phenomenon on Water Quality and Fishes in Quarun Lake, Egypt. International Journal of Environmental Science and Engineering. 3:11-23.

Ahdy, H. H. H.; Rifaat, A. E. and Draz, S. E. O. (2011). The Speciation and Potential Mobility of $\mathrm{Pb}, \mathrm{Cd}, \mathrm{Cu}$ and $\mathrm{Zn}$ in Lake Qarun Bottom Sediments, Fayioum, Egypt. JKAU: Mar. Sci., 22; 111 - 133. 
Al-Afify, A. D. G.; Othman, A. A. and Ramadan, M. A. (2018). Characterization of chemical and microbiological quality of Nile River surface water at Cairo (Egypt). Rend. Fis. Acc. Lincei https://doi.org/10.1007/s12210-018-0721-8

Ali, F. K.; El-Shafai1, S. A.; Samhan, F. A. and Khalil, W. K. B. (2008). Effect of water pollution on expression of immune response genes of Solea aegyptiaca in Lake Qarun. Afr. J. of Biotechnol. 7 (10): 1418 - 1425.

Ali, M. H. H. and Fishar, M. R. A. (2005). Accumulation of trace metals in some benthic invertebrate and fish species relevant to their concentration in water and sediment of Lake Qarun, Egypt. Egypt. J. Aquat. Res., 31(1):289-302.

Ali, M. S. and Osman, G. A. (2010). Microbial load as Pollution Indicator in Water of El-Khadra Lake at Wadi El-Natroun, Egypt, Journal of American Science, 2010;6(12).

Al-Mohammed, F.M. and Mutasher, A.A., (2013). Application of water quality index for evaluation of groundwater quality for drinking purpose in Dibdiba Aquifer, Kerbala City, Iraq. J. Babylon Univ./Eng. Sci., 21(5): 1647-1660.

Anon, (1997). Investigation of Lake Qarun Ecosystem. Final report submitted to USAID, National Institute of Oceanography and Fisheries, Cairo, Egypt, 287pp.

Anwar, S.M., El-Shafy, A.A., El-Serafy, S.S., Ibrahim, I.I. and Ali, E.A. (2001). Accumulation of Trace Elements in Fish at Lake Qarun as a Biomarker of Environmental Pollution, Journal of the Egyptian German Society of Zoology, 36(A): 443 - 461.

APHA (2005). Standard methods for examination of water and wastewater. $21^{\text {st }}$. Edn. Standard Methods is a joint publication of the American Public Health Association (APHA), the American Water Works Association (AWWA), and the Water Environment Federation (WEF). Washington DC, USA.

Authman, M. M. N. and Abbas, H. (2007). Accumulation and distribution of copper and zinc in both water and some vital tissues of two fish species (Tilapia and Mugil cephalus) of Lake Qarun, Fayoum Province, Egypt. Pakistan J. of Biologi. Sci., 10(13): 2105 - 2122.

Balan, I. N., Shivakumar, M. and Kumar, P. D. M., (2012). An assessment of ground water quality using water quality index in Chennai Tamil Nadu, India. Chronicles Young Scient. 3(2): 146 - 150.

Bhatnagar, A. and Devi, P. (2013). Water quality guidelines for the management of pond fish culture. Int. J. Environ. Sci., 3(6): 1980 - 1997

Bronmark, C. and Hansson, L. A. (2002). Environmental issues in lakes and ponds: Current state and perspectives. Environmental Conservation, 29: 290 - 307.

Brown, R. M., McCleiland, N. J.; Deininger, R. A. and O'Connor, M. F. (1972). A Water Quality Index-Crossing the Psychological Barrier. In: Jenkis, S. H. (Ed.), Proc. Int. Conf. on Water Poll. Res., Jerusalem, 6: 787 - 797.

CCME, Canadian Council of Ministers of the Environment. (2007). For the protection of aquatic life. In: Canadian environmental quality guidelines, 1999. Canadian Council of Ministers of the Environment, 1999, Winnipeg

Chowdhury, R. M., Muntasir, S. Y. and Hossain, M. M., (2012). Water quality index of water bodies along Faridpur-Barisal road in Bangladesh. Glob. Eng. Tech. Rev., 2 (3): 1-8.

Dardir, A. A. and Wali, A. M. A. (2009). Extraction of salts from lake Qaroun, Egypt: Environmental and Economic Impact. Global NEST J., 11; 106 - 113. 
Edberg, S. C.; Rice, E. W.; Karlin, R. J. and Allen, M. J. (2000). Escherichia coli: the best biological drinking water indicator for public health protection, Journal of Applied Microbiology 2000, 88, 1068-1168.

Edwards, A. C. and Withers, P. J. A. (2008). Transport and delivery of suspended solids, nitrogen and phosphorus from various souries to fresh water in the UK. J. Hydrol., 350: 144 - 153.

Elewa, A. A. (1993). Distribution of $\mathrm{Mn}, \mathrm{Cu}, \mathrm{Zn}$ and $\mathrm{Cd}$ in water, sediments and aquatic plants in River Nile and Aswan Reservoir, Egypt. J. Applied Sci., 8: $711-723$.

El-Fadaly, H.; El-Defrawy, M.; El-Zawawy, F. and Makia, D. (2001). Chemical and microbiological evaluation of River Nile water in Dakahlia Governorate. Journal of Environmental Science 22: 1-18.

El-Sayed, S.A., Moussa, E.M.M., El-Sabagh, M.E.I., (2015). Evaluation of heavy metal content in Qarun Lake, El-Fayoum, Egypt. Part I: Bottom sediments. J. Radiat. Res. Appl. Sci., 8: 276 - 285.

El-Sayed, W. M. and Mosad. Y. A. (2017). Studying of Physico-chemical and Biological characters of Qarun Lake, El-Fayoum-Egypt. Egypt. Acad. J. Biolog. Sci., 9(2): $11-20$.

El-Shabrawy, G. M., Anufriieva, E. V., Germoush, M. O.; Goher, M. E. and Shadrin, N. V. (2015). Does salinity change determine zooplankton variability in the saline Qarun Lake (Egypt)? Chin. J. Ocean. Limnol., 33(6): 1368 - 1377.

FAO, Food and Agriculture Organization (1994). Water quality for agriculture, irrigation and drainage. Rome, paper no. 29. In: Eds. Ayers RS, Westcot DW (eds) Rev. 1, M-56. ISBN 92-5-102263-1

Fathi, A. A. and Flower, R. J. (2005). Water quality and phytoplankton communities in Lake Qarun (Egypt). Aquat. Sci., 67; 350 - 362.

Fujioka, R. S.; Hashimoto, H. H.; Siwak, E. B. and Young, R. H. F. (1981). Effect of sunlight on survival of indicatorbacteria in seawater. Appl. and Environ. Microbiol., 41:640- 46.

Giannoulis, N.; Maipa, V.; Konstantinou, I.; Albanis, T. and Dimoliatis, I. (2005). Microbiological risk assessment of Agios Georgios source supplies in north western Greece based on faecal coliform determination and sanitary inspection survey. Chemosphere, 58: 1269-1276.

Gray, N. F. (1994). Drinking water quality: Problems and solutions. Chichester, UK: John Wiley \& Sons.

Gupta, G. and Abd El-Hamid, Z. (2003). Water quality of lake Qarun, Egypt. Int. J. Environ. Stud. 60; 651 - 657.

Hussein, H.; Amer, R.; Gaballah, A.; Refaat, Y. and Abdel-Wahab, A. (2008). Pollution Monitoring for Lake Qarun. Adv. Environ. Biol., (2)2: 70 - 80.

Ibrahim, L. A.; Ramzy, E. M. (2013). Water quality and its impact on Tilapia Zilli (Case Study) Qarun Lake-Egypt. Intern. Water Technolo. J., IWTJ., 3(4): 170 191.

Isobe, K. O.; Tarao, M.; Chiem, N. H.; Minh, L. Y. and Takada, H. (2004). Effect of environmental factors on the relationship between fecal indicator bacteria in tropical (Mekong Delta) and temperature (Tokyo) freshwaters. Appl. Environ. Micro., 79(2): 814-821.

Kagalou, I, Tsimarakis, G. and Paschos, I. (2001). Water chemistry and biology in a shallow lake (Lake Pamvotis-Greece). Present state and perspectives. Global Nest. Int. J., 3: 85-94. 
Karmakar, S. and Musthafa, O. M. (2013). Lakes and Reservoirs: Pollution. In:" Encyclopedia of Environmental Management". Four volume set. (Ed. Jorgensen, S. A.), published by Taylor \& Francis: New York, pp. 1576-1587. Published online: 01 May 2013; Informa Ltd Registered in England and Wales Registered Number: 1072954 Registered office: Mortimer House, 37-41 Mortimer Street, London W1T 3JH, UK., 3512 p.

Liu, T.; Wang, H.; Yang, H.; Ma, Y. and Cai, O. (2009). Detection of phosphorus species in sediments of artificial landscape lake in China by fractionation and phosphorus-31 nuclear magnetic resonance pectroscopy. Environ. Pollut., $157: 49-56$.

Lloyd, R. (1992). Pollution and Freshwater Fish. Fishing News Books, Oxford.

Mageed, A. A. (2005). Effect of some environmental factors on the biodiversity of Holozooplankton community in Lake Qarun, Egypt. Egypt. J. Aquat. Biol. \&Fish., 31(1):230-250.

Mansour, S. A. and Sidky M. M. (2003). Ecotoxicological Studies. 6. The first comparative study between Lake Qarun and Wadi El-Rayan wetland (Egypt), with respect to contamination of their major components. Food Chemistry. 82: $181-189$.

Mugnai, R.; Sattamini, A.; dos Santos, J.A. and Mangia, A.H.; (2015). A Survey of Escherichia coli and Salmonella in the Hyporheic Zone of a Subtropical Stream: Their Bacteriological, Physico-chemical and Environmental Relationships. PLoS one, 10(6):1-16.

Noble, R. T.; Lee, I. M. and Schiff, K. C. (2004). Inactivation of indicator microorganisms from various sources of faecal contamination in sea water and fresh water. J. Appl. Microbiol., 96: 464- 472.

Olayemi, A. B. (1993). Survival of Escherichia coli and some pathogenic bacteria in pond water exposed to solar and UV-irradiations. Biosci. Res. Commun., 5: pp. $11-127$.

Sabae, S. Z. (1999). Bacterial pollution of River Nile waters (Rosette branch). Egypt . J. Aquat. Biol. \& Fish., 3(2): 21-34.

Sabae, S. Z. (2004). Monitoring of microbial pollution in the River Nile and the impact of some human activities on its waters. Proceeding $3^{\text {rd }}$ International Conference on Biological Science. Tanta University. 28-29, April, 3: 200-214.

Sabae, S. Z. and Rabeh, S. A. (2007). Evaluation of the microbial quality of the River Nile waters at Damietta branch, Egypt. Egypt. J. Aqua. Res., 33(1): 301311.

Sabae, Z. S. and Mohamed, F. A.S. (2015). Effect of Environmental Pollution on the Health of Tilapia spp. from Lake Qarun. Global Veterinaria 14 (3): 304-328.

Saeed, S. M. and Mohammed, M. A. (2012). Influence of Physico-Chemical Characteristics of Water on Metals Accumulation in Water and Tilapia Zillii Inhabiting Different Habitats in Egypt. Arabian Aquaculture Society. 7(1): 29-50.

Sanders,T.G.;Ward,R.C.;Loftis,J.C.;Steele,T.D.; $\quad$ Adrian , D. D. and Yevjevich, V. (1983). Design of Networks for Monitoring Water Quality; Water Resources Publications LLC: Highlands Ranch, Colorado, USA, 1983, pp: 331.

Sayed, M. F Abdel-Satar, A. M. (2009). Chemical assessment of wadi El-rayan Lakes -Egypt.American Eurasian J. Agric. Environ. Sci., 5: 53 - 62.

Schaffter, N and Parriaux, A. (2002). Pathogenic-bacterial water contamination in mountainous catchments. Water Research. 36 (1):131-139. 
Shaaban, M. T.; Ibrahim, H. A. and Hanafi, A. A. M. (2016). Distribution of bacteria in Lake Qarun, AL Fayoum, Egypt (2014 -2015) in relation to its physical and hydrochemical characterization. J. of Biosci. and Appli Res., 2(9): 601 - 615.

Shaaban-Dessouki, S. A.; Soliman, A. I. and Deyab, M. A. (1993). Environmental characteristics and nutrients distribution in Demietta estuary of the River Nile. Journal of Environmental Science 6:159-177.

Sivri, N.; Niyazi, K. and Osman, N. V. (2007). Estimation of stream temperature in Firtina Greek (Rize-Turkiye) using artificial neural network model. J. Environ. Biol., 28: 67 - 72.

Soliman, N. F.; El Zokm, G. M. and Okbah, M. A. (2018). Risk assessment and chemical fractionation of selected elements in surface sediments from Lake Qarun, Egypt using modified BCR technique, Chemosphere, 262 271.https://doi.org/10.1016/j.chemosphere.2017.10.049.

Tripaty, J. K. and Sahu, K. C., (2005). Seasonal hydrochemistry of groundwater in the Barrier Spit system of the Chilika Lagoon, India. J. Environ. Hydrol. 13: 19.

Tyagi, S., Sharma, B., Singh, P. and Dobhal, R., (2013). Water Quality Assessment in Terms of water quality index. Am. J. Water Res., 1(3): 34-38.

US EPA, (U.S. Environmental Protection Agency). (2001). Protocol for Developing Pathogen. TMDLs, EPA841-R-002.

WHO, World Health Organization (2006). Guidelines for drinking-water quality, incorporating first addendum. Recommendations. $3^{\text {rd }}$ ed.vol. 1.; p. 515.Geneva: 